\title{
KELEBIHAN DAN KELEMAHAN MEDIA FILM SEBAGAI MEDIA PEMBELAJARAN SEJARAH
}

(Survei Pendapat mahasiswa di Jurusan Sejarah FIS-UNJ)

\section{OLEH: Ratu Husmiati}

Dosen Jurusan Sejarah FIS UNJ

\begin{abstract}
Abstrak
Penelitian ini bertujuan untuk mengetahui pendapat mahasiswa jurusan sejarah tentang kelemahan dan kelebihan media film sebagai media pembelajaran sejarah. Penelitian ini menggunakan metode deskriptif, dengan teknik survei, populasi penelitian ini adalah seluruh mahasiswa jurusan sejarah yang berjumlah 325 orang. Sebagai sample diambil 50 orang dengan cara simple random sampling. Sumber data penelitian menggunakan angket. Teknik analisa data menggunakan deskritif kuantitatif yang diperjelas dengan frekuensi dan prosentase. Ternyata media film sebagai media pembelajaran sejarah menurut pendapat mahasiswa lebih banyak memiliki kelebihan daripada kelemahannya.
\end{abstract}

\section{Pendahuluan}

Media pembelajaran menjadi mata kuliah wajib dan disahkan dalam loka karya jurusan sejarah pada bulan April 2010. Film sebagai media pembelajaran digunakan pada beberapa mata kuliah di jurusan sejarah, menjadi media yang sering digunakan dalam kegiatan perkuliahan di jurusan sejarah. Karena dengan menggunakan media film, mahasiswa dapat membangun imajinasi yang sesuai dengan tema cerita dari film yang disaksikan oleh mahasiswa.

Sebagai media pembelajaran sejarah, media film selain memiliki kelebihan juga memiliki kekurangan. Media film tampaknya dapat meningkatkan motivasi, kreatifitas dan hasil belajar mahasiswa. Tetapi media film yang seperti apa yang dapat meningkatkan motivasi belajar mahasiswa. Selain itu media film sebagai media pembelajaran sejarah dianggap mendukung, tujuan pembelajaran dan materi yang telah ditetapkan.

Media film yang digunakan menurut beberapa penuturan mahasiswa cukup menarik apabila isinya sesuai dengan materi perkuliahan yang diberikan dengan menggunakan gambar bergerak seperti film, menghilangkan rasa kebosanan dikarenakan situasi yang monoton. Media film sejarah yang dikemas secara menarik oleh sutradara dengan peran dan isi cerita mampu membawa mahasiswa berimajinasi sesuai dengan jiwa jamannya. Tetapi disamping kelebihan yang dimiliki media film sebagai media sejarah, ada beberapa kekurangan yang patut di cermati. 
Kelemahan itu antara lain: menurut mahasiswa ada film sejarah yang ceritanya kurang sistematis dan juga kurang jelas dalam alur cerita. Selain itu teralu banyak fiksi dibandingkan dengan kebenaran, sehingga terlalu berbaur antara film sejarah sebagai kisah atau sejarah sebagai ilmu.

Tampaknya perlu didiskusikan kembali antara dosen dan mahasiswa untuk mencari kebenaran sejarah. Oleh sebab itu peneliti tertarik untuk meneliti kelebihan dan kekurangan media film sebagai media pembelajaran sejarah di jurusan sejarah. penelitian dirumuskan sebagai berikut ; Apakah kelebiahan dan kelemahan media film sebagai media pembelajaran sejarah di Jurusan FIS UNJ.

\section{PEMBAHASAN BERUPA HASIL PENELITIAN}

\section{1 Kelebihan Media Film Sebagai Media Pembelajaran \\ a. Membuat Perkuliahan Menarik dan Bervariasi}

Banyak media yang digunakan dalam proses pembelajaran sejarah seperti transparansi , slide, audio tape, film, kompulis, permainan, televisi dll.

Dari sekian banyak media yang dapat diterapkan media film merupakan salah satu alternatif proses pembelajaran di kelas. Film merupakan pembelajaran media bergerak dengan media audio ternyata membuat perkuliahan menarik dan bervariasi sebagai media pembelajaran dalam perkuliahan di Jurusan sejarah, hal ini dapat dilihat pada tabel di bawah ini :
Tabel 1

\section{Membuat Perkuliahan Menarik dan Bervariasi}

\begin{tabular}{|c|l|c|c|}
\hline No. & $\begin{array}{l}\text { Bagaimana } \\
\text { kegiatan } \\
\text { pembelajaran yang } \\
\text { menggunakan } \\
\text { media film dalam } \\
\text { perkuliahan di } \\
\text { Jurusan Sejarah.... }\end{array}$ & Responden & $\%$ \\
\hline a & $\begin{array}{l}\text { Sangat bervariasi } \\
\text { dan sangat menarik }\end{array}$ & 12 & 24 \\
b & $\begin{array}{l}\text { Bervariasi dan } \\
\text { menarik bervariasi }\end{array}$ & 1 & 74 \\
c & $\begin{array}{l}\text { Kurang beran menarik } \\
\text { dan mervariasi }\end{array}$ & - & - \\
d & $\begin{array}{l}\text { Tidak beran menarik } \\
\text { dan }\end{array}$ & - & - \\
e & Lainnya..... & \\
\hline
\end{tabular}

Ternyata 12(24\%) responden menjawab bahwa kegiatan pembelajaran yang menggunakan media film dalam perkuliahan membuat proses perkuliahan menjadi sangat menarik dan sangat variatif, 37(74\%) responden menjawab media film membuat perkuliahan bervariasi dan menarik dan hanya $1(2 \%)$ saja yang dinyatakan kurang bervariasi dan tidak menarik pembelajaran yang menggunakan media film.

Hal ini membuktikan bahwa media film memiliki kelebihan sehingga dapat membuat proses pembelajaran dalam perkuliahan menjadi sangat menarik dan bervariasi. Ini juga berkaitan dengan kelebihan media film yang disajikan dalam mata kuliah di Jurusan Sejarah dapat membawa secara tidak langsung mahasiswa sebagai responden dari suatu negara ke negara lain, ini dibuktikan dengan 39(78\%) responden merespon demikian 9(18\%) menjawab sangat mampu membawa secara tidak 
langsung dari satu negara ke negara lain, 5(10\%) yang menjawab tidak bias secara langsung membawa dari satu negara ke negara lain. Selain itu 38(76\%) menjawab kelebihan media film dapat membawa responden dari satu masa ke masa yang lain 6(12\%) menjawab sangat membawa responden dari satu masa ke masa yang lain dan 6(12\%) lainnya menjawab kurang dapat membawa responden dari satu masa ke masa yang lain.

Dari jawaban-jawaban di atas tampak keunggulan media film dengan menggunakan media film dapat mengkonkritkan sesuatu yang sebelumnya abstrak, film juga dapat menembus ruang dan waktu sehingga ini membuat lebih variatif dan menarik perhatian mahasiswa daripada hanya membaca buku sejarah untuk suatu peristiwa sejarah atau mendengar ceramah dan berdiskusi saja.

Tidak dapat dipungkiri sejarah adalah ilmu tentang waktu. Dalam film sebagai media pembelajaran sejarah responden secara tidak langsung dapat melihat masa atau waktu . sejarah adalah ilmu tentang waktu itu dapat melewati 4 hal yaitu perkembangan, kesinambungan, pengulangan dan perubahan. Media film mampu membawa responden secara tidak langsung dari waktu ke waktu yang lain tentang peristiwa sejarah untuk latar terjadinya peristiwa media film juga mampu membawa responden dari latar/tempat yang satu ke tempat yang lain secara tidak langsung. Media film dapat membuat perkuliahan menjadi menarik dan bervariatif.

\section{b. Merangsang Imajinasi}

Selain itu media film juga dapat merangsang imajinasi mahasiswa. Hal ini dapat di lihat pada tabel di bawah ini :

\section{Tabel 2}

\section{Merangsang Imajinasi}

\begin{tabular}{|c|l|c|c|}
\hline No. & $\begin{array}{l}\text { Bagan film, anda } \\
\text { dapat melihat } \\
\text { kejadian f } \\
\text { peristiwa sejarah } \\
\text { secara nyata hal } \\
\text { ini dapat }\end{array}$ & Responden & \% \\
\hline a & $\begin{array}{l}\text { Sangat } \\
\text { merangsang } \\
\text { imajinasi anda }\end{array}$ & $\mathbf{1 8}$ & $\mathbf{3 6}$ \\
b & $\begin{array}{l}\text { Merangsang } \\
\text { imajinasi anda }\end{array}$ & $\mathbf{2 4}$ & $\mathbf{4 8}$ \\
c & $\begin{array}{l}\text { Kurang } \\
\text { merangsang } \\
\text { imajinasi anda } \\
\text { Tidak } \\
\text { merangsang } \\
\text { imajinasi anda }\end{array}$ & $\mathbf{5}$ & $\mathbf{1 0}$ \\
e & \begin{tabular}{l} 
Lainnya...... \\
\hline
\end{tabular}
\end{tabular}

Hasil penelitian dari tabel di atas menyatakan $18(36 \%)$ menyatakan media film dapat sangat merangsang imajinasi, 24(48\%) dapat merangsang imajinasi, hanya 5(10\%) kurang merangsang imajinasi dan hanya $3(6 \%)$ yang tidak merangsang imajinasi.

\section{c. Kritis Memahami Peristiwa Sejarah}

Dengan kegunaaan media film dapat merangsang imajinasi, sebagian responden ini akan membuat imajinasi dan cara berfikir mahasiswa sebagai responden lebih berkembang sehingga dapat membuat mahasiswa lebih kritis memahami peristiwa sejarah. Hal ini dibuktikan dengan tabel di bawah ini : 
Tabel 3

Kritis Memahami Peristiwa

Sejarah

\begin{tabular}{|c|c|c|c|}
\hline $\begin{array}{c}\text { No. } \\
2\end{array}$ & $\begin{array}{l}\text { Apakah film } \\
\text { membuat } \\
\text { anda... }\end{array}$ & Responden & $\%$ \\
\hline $\mathrm{a}$ & $\begin{array}{l}\text { Sangat kritis } \\
\text { memahami } \\
\text { peristiwa sejarah }\end{array}$ & 14 & 28 \\
\hline b & $\begin{array}{l}\text { Kritis memahami } \\
\text { peristiwa sejarah }\end{array}$ & 26 & 52 \\
\hline c & $\begin{array}{l}\text { Kurang kritis } \\
\text { memahami } \\
\text { peristiwa sejarah }\end{array}$ & 10 & 20 \\
\hline $\mathrm{d}$ & $\begin{array}{l}\text { Tidak kritis } \\
\text { memahami } \\
\text { peristiwa sejarah }\end{array}$ & - & - \\
\hline $\mathrm{e}$ & Lainnya...... & - & - \\
\hline
\end{tabular}

Dari hasil di atas dapat dilihat 26(52\%) menyatakan media film membuat para responden kritis memahami peristiwa sejarah, 14(28\%) sangat kritis memahami peristiwa sejarah hanya $10(20 \%)$ responden kurang memahami peristiwa sejarah.

\section{d. Mempermudah untuk \\ Menjelaskan Peristiwa}

Hal ini berkaitan dengan penggunaan dalam media film dapat mempermudah dan bagus untuk menjelaskan suatu peristiwa sejarah, ini dibuktikan dengan bagus dan mempermudah media film menjelaskan peristiwa sejarah dapat dilihat pada tabel di bawah ini :
Tabel 4

Mempermudah untuk

Menjelaskan Peristiwa

\begin{tabular}{|c|c|c|c|}
\hline $\begin{array}{l}\mathbf{N} \\
\mathbf{o}\end{array}$ & $\begin{array}{l}\text { Apakah penggunaan } \\
\text { media film sebagai } \\
\text { media dalam } \\
\text { perkuliahan di jurusan } \\
\text { sejarah dapat ....... }\end{array}$ & $\begin{array}{c}\text { Respon } \\
\text { den }\end{array}$ & $\%$ \\
\hline $\mathrm{a}$ & $\begin{array}{l}\text { Lebih mempermudah } \\
\text { untuk menjelaskan suatu } \\
\text { peristiwa sejarah }\end{array}$ & 18 & 36 \\
\hline $\mathrm{b}$ & $\begin{array}{l}\text { Mempermudah untuk } \\
\text { menjelaskan suatu } \\
\text { peristiwa sejarah }\end{array}$ & 24 & 48 \\
\hline $\mathrm{c}$ & $\begin{array}{l}\text { Kurang mempermudah } \\
\text { untuk menjelaskan } \\
\text { peristiwa sejarah }\end{array}$ & 5 & 10 \\
\hline $\mathrm{d}$ & $\begin{array}{l}\text { Tidak mempermudah } \\
\text { untuk menjelaskan } \\
\text { peristiwa sejarah }\end{array}$ & 3 & 6 \\
\hline $\mathrm{e}$ & Lainnya..... & - & - \\
\hline
\end{tabular}

Ternyata media film dapat mempermudah dan bagus untuk menjelaskan peristiwa sejarah 24(48\%) menjawab demikian, $18(26 \%)$ berpendapat sangat mempermudah dan bagus untuk menjelaskan peristiwa sejarah hanya $5(10 \%)$ dan $3(6 \%)$ yang berpendapat kurang dan tidak mempermudah dan bagus untuk menjelaskan peristiwa sejarah.

\section{e. Mengkongkritkan yang} Abstrak

Tabel di bawah ini juga memperlihatkan para responden berpendapat bahwa media film sebagai media sejarah dapat menjelaskan realitas sejarah dari suatu peristiwa masa lalu yang abstrak dapat dikongkritkan dalam waktu yang singkat. 
Tabel 5

\section{Mengkongkritkan yang Abstrak}

\begin{tabular}{|c|l|l|c|}
\hline No.9 & $\begin{array}{l}\text { Apakah film } \\
\text { menjelaskan } \\
\text { peristiwa masa } \\
\text { lalu secara } \\
\text { 5able5ies dalam } \\
\text { waktu singkat ? }\end{array}$ & Responden & \% \\
\hline a & $\begin{array}{l}\text { Dalam waktu } \\
\text { sangat singkat } \\
\text { Dalam waktu } \\
\text { singkat } \\
\text { balam waktu } \\
\text { kurang singkat } \\
\text { Dalam waktu tidak } \\
\text { singkat }\end{array}$ & 10 & 20 \\
e & Lainnya...... & - & 10 \\
\hline
\end{tabular}

Sangat jelas bahwa dapat menjadi realitis dalam waktu singkat $35(70 \%)$ responden menjawab demikian 10(20\%) sangat realitis dan hanya 5(10\%) saja yang menjawab kurang ini membuktikan bahwa media film dapat mengkongkritkan (menghadirkan realitis) dari sebelumnya abstrak dalam waktu singkat

\section{f. Cepat Mengingat dan}

\section{Memahami Peristiwa Sejarah}

Setelah melihat film yang disajikan dalam perkuliahan ternyata media film sebagai media pembelajaran sejarah mampu membuat mahasiswa cepat mengingat dan memahami peristiwa sejarah. Ini dibuktikan dalam table di bawah ini :
Tabel 6

\section{Cepat Mengingat dan Memahami Peristiwa Sejarah}

\begin{tabular}{|c|l|c|c|}
\hline $\begin{array}{c}\text { No. } \\
\text { 6 }\end{array}$ & $\begin{array}{l}\text { Setelah melihat film } \\
\text { yang disajikan dalam } \\
\text { perkuliahan di } \\
\text { Jurusan } \\
\text { Sejarah,dapat } \\
\text { membuat anda... }\end{array}$ & $\begin{array}{c}\text { Respon } \\
\text { den }\end{array}$ & \% \\
\hline a & $\begin{array}{l}\text { Sangat cepat mengingat } \\
\text { dan memahami suatu } \\
\text { peristiwa sejarah } \\
\text { Cepat mengingat dan } \\
\text { mamahami suatu } \\
\text { peristiwa sejarah } \\
\text { Tidak cepat mengingat } \\
\text { dan memahami suatu } \\
\text { peristiwa sejarah } \\
\text { Kurang cepat mengingat } \\
\text { dan memahami suatu } \\
\text { peristiwa sejarah }\end{array}$ & 2 & 58 \\
e & $\begin{array}{l}\text { Lainnya..... } \\
\text { d. }\end{array}$ & 10 \\
\hline
\end{tabular}

Dari hasil penelitian didapatkan jawaban responden yang terbanyak $38(76 \%)$ yang cepat mengingat dan memahami suatu peristiwa sejarah baik menggunakan media film. 8(16\%) sangat cepat mengingat dan memahami suatu peristiwa sejarah, 5(10\%) tidak cepat mengingat dan memahami suatu peristiwa sejarah dan hanya 2(4\%) yang kurang memahami peristiwa sejarah.

Hal ini sejalan dengan kelebihan film sebagai media pembelajaran sejarah yaitu pesan yang digunakan mudaj dipahami 35(70\%) responden, 9(18\%) yang memilih sangat mudah dipahami pesan yang disampaikan. Hanya 4(8\%) atau 2(4\%) saja yang tidak dan kurang memahami pesan yang disampaikan. 


\section{g. Film Sebagai Audio Visual yang Menyenangkan}

Dari berbagai kelebihan media film sebagai media pembelajaran sejarah ternyata film sebagai media audio visual yang menampilkan gambar yang bergerak dan bersuara yang digunakan di jurusan sejarah menyenangkan bagi mahasiswa sebagai responden, hal ini dapat di lihat dari table di bawah ini :

Tabel 7

\section{Film Sebagai Audio Visual yang Menyenangkan}

\begin{tabular}{|c|c|c|c|}
\hline $\begin{array}{r}\text { No. } \\
22\end{array}$ & $\begin{array}{l}\text { Menurut anda } \\
\text { film sebagai } \\
\text { media audio } \\
\text { visual yang } \\
\text { menampilkan } \\
\text { gambar yang } \\
\text { bergerak dan } \\
\text { bersuara } \\
\text { membuat } \\
\text { perkuliahan } \\
\text { menjadi .... }\end{array}$ & Responden & $\%$ \\
\hline $\mathrm{a}$ & $\begin{array}{l}\text { Sangat } \\
\text { menyenangkan }\end{array}$ & 12 & 24 \\
\hline b & Menyenagkan & 33 & 66 \\
\hline $\mathrm{c}$ & $\begin{array}{l}\text { Kurang } \\
\text { menyenangkan }\end{array}$ & 5 & 10 \\
\hline $\mathrm{d}$ & $\begin{array}{l}\text { Tidak } \\
\text { menyenagkan }\end{array}$ & - & - \\
\hline $\mathrm{e}$ & Lainnya..... & - & - \\
\hline
\end{tabular}

Dapat dilihat sebanyak 12(24\%) responden menganggap film sebagai media audio visual menjadikan perkuliahan menjadi sangat menyenangkan,33(66\%) menyenangkan perkuliahan yang menggunakan film, hanya 5(10\%) saja yang berpendapat kurang menyenangkan perkuliahan menggunakan media film.

\section{h. Membuat Perkuliahan Efektif dan Aktif}

Ternyata selain media film menyenangkan mahasiswa, media film juga membantu mahasiswa belajar secara aktif dan menciptakan pembelajaran yang efektif. Hal ini berkaitan dengan table di bawah ini

Tabel 8

\section{Membuat Perkuliahan Efektif dan Aktif}

\begin{tabular}{|c|l|c|c|}
\hline $\begin{array}{c}\text { No. } \\
7\end{array}$ & $\begin{array}{l}\text { Apakah suatu } \\
\text { peristiwa yang } \\
\text { ditampilkan } \\
\text { dengan } \\
\text { menggunakan } \\
\text { media film } \\
\text { dalam } \\
\text { perkuliahan } \\
\text { dapat membuat } \\
\text { anda.... }\end{array}$ & Responden & \% \\
\hline a & $\begin{array}{l}\text { Lebih aktif dalam } \\
\text { memperoleh } \\
\text { pengalaman } \\
\text { secara tidak }\end{array}$ & 10 & 20 \\
b & $\begin{array}{l}\text { langsung } \\
\text { Aktif dalam } \\
\text { memperoleh } \\
\text { pengalaman } \\
\text { secara tidak }\end{array}$ & 32 & 64 \\
c & $\begin{array}{l} \\
\text { langsung } \\
\text { Kurang aktif } \\
\text { dalam } \\
\text { memperoleh } \\
\text { pengalaman } \\
\text { secara tidak } \\
\text { langsung } \\
\text { Tidak aktif dalam } \\
\text { memperoleh } \\
\text { pengalaman } \\
\text { secara tidak } \\
\text { langsung } \\
\text { Lainnya.... }\end{array}$ & & \\
\hline & & \\
\\
\end{tabular}

Dari hasil penelitian di atas didapat 32(64\%) responden, yang membuat mahasiswa menjadi aktif 
dalam memperoleh pengalaman secara tidak langsung, 10(20\%) menjadi lebih aktif hanya 6(12\%) dan 2(4\%) saja yang kurang aktif dan tidak aktif. Hal ini membantu mahasiswa untuk mengembangkan kemajuan berfikir mahasiswa menjadi lebih intelektual, menganalisis dan dapat menerapkan pengetahuannya.

\section{i. Meningkatkan Hasil Belajar}

Kelebihan media film sebagai media pembelajaran sejarah selain menarik, menyenangkan dan membuat motivasi untuk belajar dapat juga meningkatkan hasil belajar sejarah mahasiswa dalam perkuliahan. Hal ini dapat dilihat pada table di bawah ini:

Tabel 9

Meningkatkan Hasil Belajar

\begin{tabular}{|c|l|c|c|}
\hline $\begin{array}{c}\text { No. } \\
\text { 30 }\end{array}$ & $\begin{array}{l}\text { Apakah } \\
\text { penggunaan } \\
\text { media film } \\
\text { dapat memacu } \\
\text { mahasiswa } \\
\text { untuk..... }\end{array}$ & Responden & \% \\
\hline a & $\begin{array}{l}\text { Meningkatkan } \\
\text { hasil belajar } \\
\text { menjadi lebih } \\
\text { baik }\end{array}$ & 14 & 28 \\
b & $\begin{array}{l}\text { Meningkatkan } \\
\text { hasil belajar } \\
\text { menjadi baik } \\
\text { c }\end{array}$ & $\begin{array}{l}\text { Kurang } \\
\text { meningkatkan } \\
\text { hasil belajar } \\
\text { menjadi baik } \\
\text { Tidak } \\
\text { meningkatkan } \\
\text { hasil belajar } \\
\text { menjadi baik } \\
\text { Lainnya .... }\end{array}$ & 58 \\
e & 29 & 14 \\
\hline
\end{tabular}

Dari hasil di atas dapat dilihat 29(58\%) responden menyatakan dapat menghasilkan hasil belajar menjadi baik 14(28\%) menjadi lebih baik, hanya $7(14 \%)$ yang menyatakan kurang meningkatnya hasil belajar mahasiswa dengan menggunakan media film terkait materi tujuan perkuliahan. Ternyata perkuliahan yang diikuti memakai media film berhubungan dengan materi perkuliahan 35(70\%) responden berpendapat demikian, 10(20\%) menyatakan sangat berhubungan antara film yang digunakan dengan materi perkuliahan, hanya 5(10\%) saja yang berpendapat kurang berhubungan. Begitu pula media film yang digunakan sangat berhubungan dengan kebutuhan dan tujuan perkuliahan $10(20 \%)$ responden berfikir demikian, 32(64\%) menyatakan berhubungan dengan kebutuhan dan tujuan perkuliahan, hanya $8(16 \%)$ saja yang berpendapat kurang berhubungan dengan kebutuhan dan tujuan perkuliahan.

\section{2 Kelemahan Media Film}

\section{a. Media Film Memerlukan Tempat dan waktu}

Di jurusan sejarah, dosen melihat rata-rata menggunakan media film hanya 2-3 kali saja hal ini dikaitkan dengan jawaban para responden 20(40\%) menjawab demikian. $10(20 \%)$ responden menjawab 3-4 kali dan 8(16\%) responden menjawab 4-5 kali 8(16\%) 1 kali dan ada juga mata kuliah yang tidak memakai media film sebagai media pembelajaran, lebih jelas lihat tabel di bawah ini : 
Tabel 10

Intensitas Menonton

\begin{tabular}{|c|l|c|c|}
\hline $\begin{array}{c}\text { No. } \\
20\end{array}$ & $\begin{array}{l}\text { Berapa kali } \\
\text { dari mata } \\
\text { kuliah } \\
\text { menggunakan } \\
\text { media film di } \\
\text { jurusan } \\
\text { sejarah, selama } \\
\text { mengikuti } \\
\text { perkuliahan? }\end{array}$ & Responden & $\%$ \\
\hline a & $4-5$ kali & & \\
b & $3-4$ kali & 8 & 16 \\
c & $2-3 k a l i$ & 10 & 20 \\
d & 1 kali & 8 & 16 \\
e & Lainnya ..... & 4 & 8 \\
\hline
\end{tabular}

Media film di jurusan sejarah yang memerlukan tempat dan waktu tersendiri. Di jurusan sejarah biasanya menonton film difokuskan di laboratorium sejarah dan durasi memutar film butuh waktu panjang melebihi jam perkuliahan.

Hal ini dibuktikan dengan 45(90\%) menyatakan melihat film di laboratorium sejarah karena di sana dilengkapi berbagai sarana untuk menonton dan memutar film, hanya $5(10 \%)$ saja yang menggunakan ruang perkuliahan untuk menonton film.

\section{b. Media Film Perlu Biaya Mahal dan Pembuatannya Butuh Waktu lama}

Pengadaan media film butuh biaya mahal dan waktu lama. Ini didukung oleh pernyataan $37(78 \%)$ responden menyatakan butuh biaya mahal dan waktu lama, 8(16\%) menyatakan butuh biaya sangat mahal dan waktu yang sangat lama. Hanya 5(10\%) saja yang menyatakan butuh waktu singkat dan biaya murah kegiatan tersebut dapat di lihat pada tabel di bawah ini :
Tabel 11

Butuh Biaya dan Waktu

\begin{tabular}{|c|l|c|c|}
\hline $\begin{array}{c}\text { No. } \\
26\end{array}$ & $\begin{array}{l}\text { Apakah menurut } \\
\text { anda persoalan } \\
\text { media film yang } \\
\text { digunakan } \\
\text { dalam } \\
\text { perkuliahan di } \\
\text { Jurusa Sejarah } \\
\text { memerlukan...... }\end{array}$ & Responden & \% \\
\hline a & $\begin{array}{l}\text { Biaya sangat mahal } \\
\text { dan waktu yang } \\
\text { sangat lama } \\
\text { Biaya mahal dan } \\
\text { waktu yang lama } \\
\text { Kurang murah dan } \\
\text { waktu tidak singkat } \\
\text { Tidak perlu biaya } \\
\text { dan waktu }\end{array}$ & 8 & 16 \\
e & $\begin{array}{l}\text { Lainnya.... } \\
\text { daingan }\end{array}$ & 10 \\
\hline
\end{tabular}

Karena mahal dan butuh waktu rata-rata film yang dipakai sebagai media dalam perkuliahan sebagian besar diproduksi dari luar jurusan 40(80\%) menyatakan demikian, hanya 5(10\%) yang diproduksi di jurusan untuk kebutuhan sendiri waktu juga diperlukan dalam pengadaanya butuh waktu tersendiri dan biaya listrik, jika listrik mati tidak tabel memutar film.

\section{c. Media Film Tidak Dapat Menggambarkan Realitas Sebenarnya}

Di jurusan sejarah film drama yang bertema sejarah, sering digunakan sebagai media film dalam perkuliahan di jurusan sejarah $31(62 \%)$ responden menjawab demikian 8(16\%) menjawab sangat setuju. Hanya 9(18\%) dan 3(6\%) responden yang menjawab kurang dan tidak setuju. Film drama yang bertema sejarah tidak dapat menggambarkan fakta secara kongkrit karena sejarah 
sangat berkaitan dengan waktu dan kebenaran peristiwa. Selain film drama, film dokudrama yang menyangkut kisah dari kehidupan nyata sering digunakan sebagai media film dalam perkuliahan di jurusan sejarah 30(60\%) berpendapat demikian 5(10\%) sangat setuju 10(20\%) kurang setuju dan 5(10\%) tidak setuju, film docudrama yang tidak dapat menggambarkan fakta sejarah secara kongkrit secara keseluruhan.

Film dokumenter merupakan film yang paling banyak disajikan di jurusan sejarah 14(28\%) menyatakan kebanyakan film tersebut bersifat dokumenter. 26(52\%) bersifat documenter. Hanya 9(18\%) berpendapat tidak dan $1(2 \%)$ berpendapat kurang bersifat dokumenter. Dapat dilihat table di bawah ini :

Tabel 12

Film Dokumenter

\begin{tabular}{|c|c|c|c|}
\hline $\begin{array}{l}\text { No. } \\
14\end{array}$ & $\begin{array}{l}\text { Kebanyakan } \\
\text { film-film yang } \\
\text { disajikan } \\
\text { dalam mata } \\
\text { kuliah } \\
\text { dijurusan } \\
\text { sejarah.... }\end{array}$ & Responden & $\%$ \\
\hline$a$ & $\begin{array}{l}\text { Lebih bersifat } \\
\text { dokumenter }\end{array}$ & 14 & 28 \\
\hline $\mathrm{b}$ & $\begin{array}{l}\text { Bersifat } \\
\text { dokumenter }\end{array}$ & 26 & 52 \\
\hline $\mathrm{c}$ & $\begin{array}{l}\text { Tidak bersifat } \\
\text { dokumenter }\end{array}$ & 9 & 18 \\
\hline $\mathrm{d}$ & $\begin{array}{l}\text { Kuarang bersifat } \\
\text { dokumenter }\end{array}$ & 1 & 2 \\
\hline $\mathrm{e}$ & Lainnya.... & - & - \\
\hline
\end{tabular}

Meskipun film dokumenter dapat menampilkan rekaman penting dari peristiwa sejarah manusia namun film dokumenter tidak dapat menggambarkan fakta secara kongkrit karena fakta dan sejarah memerlukan kritik untuk membuktikan kebenarannya. Di jurusan sejarah film dokumenter tentang sejarah nasional sangat sulit didapat, karena dimiliki oleh kalangan terbatas.

\section{d.Dengan Media Film Dosen} Tidak Bisa Mengukur pengetahuan Mahasiswa secara Maksimal dan Mengontrol Apa Yang Dipikirkan Mahasiswa

Disebabkan hal tersebut setelah menyaksikan film, dosen mewajibkan mahasiswa untuk membuat laporan individu 22(44\%) responden mengatakan demikian, 20(40\%) responden diharuskan membuat laporan secara kelompok hanya 8(16\%) tidak diwajibkan membuat laporan individu, untuk lebih jelas dilihat pada table di bawah ini:

Tabel 13

\section{Wajib Membuat Laporan Setelah Menonton Film}

\begin{tabular}{|c|l|c|c|}
\hline No & $\begin{array}{l}\text { Setelah } \\
\text { menyaksikan film } \\
\text { 2. }\end{array}$ & $\begin{array}{c}\text { Responde } \\
\text { yang digunakan } \\
\text { sebagai media } \\
\text { perkuliahan, } \\
\text { dosen meminta } \\
\text { anda untuk.... }\end{array}$ & \% \\
\hline a & $\begin{array}{l}\text { Anda diwajibkan } \\
\text { membuat laporan } \\
\text { secara individu }\end{array}$ & 22 & 4 \\
b & $\begin{array}{l}\text { Anda diwajibkan } \\
\text { membuat laporan } \\
\text { cecara kelompok }\end{array}$ & 20 & 4 \\
c & $\begin{array}{l}\text { Anda tidak } \\
\text { diwajibakbnamembu } \\
\text { at laporan secara } \\
\text { individu }\end{array}$ & 8 & 16 \\
d & $\begin{array}{l}\text { Anda tidak } \\
\text { diwajibakbnamembu } \\
\text { at laporan secara } \\
\text { individu }\end{array}$ & & \\
e & Lainnya...... & & \\
\hline
\end{tabular}


Kelemahan lain yang tidak dilihat dosen adalah mengontrol dan mengukur pengetahuan dan pikiran siswa karena itu setelah menyaksikan film, bagus dan yang mewajibkan untuk mendiskusikan film tersebut dengan dosen yang bersangkutan 21(42\%) mendiskusikan film tersebut secara kelompok 20(40\%), hanya 7(14\%) yang tidak mendiskusikannya dengan dosen dan 2(4\%) yang tidak mendiskusikannya dengan kelompok.Hal ini dapat dilihat sesuai dengan table di bawah ini:

\section{Tabel 14}

\section{Wajib mendiskusikan Film yang Disajikan}

\begin{tabular}{|c|c|c|c|}
\hline $\begin{array}{l}\text { No } \\
\dot{23}\end{array}$ & $\begin{array}{l}\text { Setelah menyaksikan } \\
\text { film yang digunakan } \\
\text { sebagai media dalam } \\
\text { perkuliahan..... }\end{array}$ & $\begin{array}{l}\text { Respon } \\
\text { den }\end{array}$ & $\%$ \\
\hline $\mathrm{a}$ & $\begin{array}{l}\text { Anda mendiskusikan film } \\
\text { tersebut dengan dosen } \\
\text { mata kuliah }\end{array}$ & 21 & $\begin{array}{l}4 \\
2\end{array}$ \\
\hline $\mathrm{b}$ & $\begin{array}{l}\text { Anda tidak } \\
\text { mendiskusikan film } \\
\text { tersebut dengan dosen }\end{array}$ & 7 & 14 \\
\hline $\mathrm{c}$ & $\begin{array}{l}\text { Anda mendiskusikan film } \\
\text { tersebut dengan teman }\end{array}$ & 20 & $\begin{array}{l}4 \\
0\end{array}$ \\
\hline $\mathrm{d}$ & $\begin{array}{l}\text { Anda mendiskusikan film } \\
\text { tersebut dengan } \\
\text { kelompok }\end{array}$ & 2 & 4 \\
\hline $\mathrm{e}$ & Lainnya..... & - & - \\
\hline
\end{tabular}

Setelah menyaksikan film sebagai media pembelajaran untuk mengukur pengetahuan mahasiswa terhadap pemahaman film yang telah ditonton, biasanya dosen meminta untuk diadakan diskusi di kelas.
Kesimpulan, Implikasi dan Saran

\section{A.Kesimpulan}

Dari hasil penelitian ini dapat disimpulkan bahwa media film sebagai media pembelajaran di jurusan sejarah banyak bertema sejarah baik itu bersifat drama, dokudrama, atau dukumenter, kelebihan media film ini mampu membuat perkuliahan menjadi bervariasi, menyenangkan, mudah dipahami, mampu merangsang imajinasi, mengkongkritkan peristiwa yang sebelumnya abstrak dalam waktu singkat dan dapat membawa mahasiswa menembus ruang dan waktu secara tidak langsung karena media film sesuai dengan materi, kebutuhan dan tujuan perkuliahan. Hal ini dapat membantu mahasiswa dalam meningkatkan hasil belajar.

Kelemahan media film sebagai media pembelajaran karena memerlukan tempat dan waktu. Laboratorium sejarah merupakan tempat paling sering digunakan mahasiswa untuk menonton film. Pembuatannya memerlukan biaya yang mahal dan sangat tergantung secara teknis pada listrik dan berbagai alat terkait. Media film juga tidak dapat menggambarkan realitas yang sebenarnya dan juga tidak mampu mengontrol pikiran dan mengukur pengetahuan mahasiswa selama menonton film. Karena itu dosen sudah menugaskan mahasiswa untuk pembuatan laporan dan mendiskusikannya setelah menonton film tersebut. 
Mahasiswa dan dosen telah mampu membuat perkuliahan menjadi efektif dan aktif dengan menggunakan media film. Media film sebagai media pembelajaran sejarah ternyata lebih banyak memiliki kelebihan daripada

kelemahan, media film tampaknya telah menjadi media yang unggul untuk pembelajaran sejarah.

\section{B. Implikasi}

Hasil penelitian ini berimplikasi media film mampu meningkatkan motivasi belajar mahasiswa yang menyebabkan meningkatnya hasil belajar mahasiswa. Dari hasil penelitian tersebut, ditekankan agar dosen dan jurusan sejarah mampu memaksimalkan penggunaan media film yang bertema sejarah untuk meningkatkan mutu perkuliahan di jurusan sejarah.

\section{Saran}

Berdasarkan kesimpulan dan implikasi di atas, maka saran yang diajukan peneliti antara lain :

1. Bagi dosen disarankan untuk menggunakan media film sebagai media pembelajaran sejarah dengan menambahkan film dokumenter dari arsip nasional yang masih sangat kurang.

Film yang memerlukan waktu panjang di luar jam perkuliahan dapat dipersingkat jam tayangnya. Caranya dengan mengatur durasi waktu sesuai dengan waktu perkuliahan. Dapat juga memberi tugas kepada mahasiswa untuk menonton film secara individu di rumah kemudian membuat laporan dan mendiskusikannya dengan teman di kelas.

2. Untuk jurusan sejarah sebagai fasilitator utama. Agar dapat memanfaatkan dan memaksimalkan berbagai sumber dan teknologi belajar. Terutama laboratorium sejarah agar menjadi tempat yang nyaman dan menyenangkan bagi mahasiswa untuk belajar dan menggunakan media film sebagai media pembelajaran sejarah yang ditayangkan di tempat tersebut, sehingga mampu meningkatkan kualitas perkuliahan untuk dosen dan mahasiswa.

3. Setelah penelitian ini selesai diharapkan ada penelitian lanjutan atau penelitian yang menggunakan media film sejarah sebagai media pembelajaran di kelas. Dengan media film sebagai media perkuliahan dapat diteliti agar dapat menjadi sarana belajar yang maksimal bagi dosen dan mahasiswa.

\section{DAFTAR PUSTAKA}

Abdul Gofur, Fungsi Media Audio Visual dan Kegiatan Belajar Mengajar. Jurnal Kependidikan, No.1.vol 10, IKIP Yogyakarta. 1980

Arsyad, Azhar. Media Pembelajaran, Jakarta : PT Raja Grafindo Persada.

Amir, Hamzah Sulaeman. Media Audiovisual : Untuk Pengajaran, 
Penerangan, Penyuluhan. Jakarta : PT Gramedia. 1985.

Chairil. Media Handout. Artikel dalam http://Blogger.com/2009/02/ diakses tanggal 15 Febuari 2010

Hamalik, Oemar. Metodologi Pengajaran Ilmu Pendidikan, Bandung : Mandar Maju, 1989

Kuntowijoyo. Pengantar Ilmu Sejarah. Yogyakarta : Yayasan Bintang Budaya. 2001.

Moh. Nasir. Metode Penelitian.Jakarta : Ghalia Indonesia.1988.

Nana Sudjana. Penelitian Hasil Belajar Mengajar. Bandung____ Remaja Rosdakarya, 1991.

Nasution. Teknologi Pendidikan. Jakarta : Bumi Aksara. 2005.

Nurul Zuriah, Metodologi Penelitian. Jakarta : Bumi Aksara. 2006

Sadiman, Arief S. Media Pendidikan : Pengertian, Pengembangan dan Pemanfaatannya, Jakarta : CV. Rajawali, 1990

Slameto. Belajar dan Faktor-faktor yang mempengaruhi, Jakarta : Bina Aksara, 1986

Soewarso, Cara-cara Penyampaian Pendidikan Sejarah Untuk Membangkitkan Minat Peserta Didik Mempelajari Sejarah Bangsanya. Jakarta : Depdiknas, 2000

Suryo, Joko. " Pelajaran Sejarah yang Baik, Sebuah Catatan". Makalah.
Disajikan dalam seminar pendidikan sejarah Yogyakarta : IKIP Yogyakarta, 1994. 